\title{
Further follow up of mortality in a United Kingdom oil refinery cohort
}

\author{
Lesley Rushton
}

\begin{abstract}
The results of an extension of follow up (1976 to 1989) of a cohort of workers employed for at least one year between 1 January 1950 and 31 December 1975 at eight oil refineries in Britain are reported. Over $99 \%$ of the workers were successfully traced to determine their vital status at 31 December 1989. The mortality observed was compared with that expected from the death rates of all the male population of England and Wales and Scotland. The mortality from all causes of death for the total study population was lower than that of the comparison population, and reduced mortality was also found for many of the major nonmalignant causes of death. Raised mortality patterns were found for diseases of the arteries, in particular aortic aneurysm, and accidental fire and explosion, for the total study population, and across several refineries and other subgroups. Mortality from all neoplasms was lower than expected overall, largely due to a deficit of deaths from malignant neoplasm of the lung. Raised mortality from all neoplasms was found for labourers and in particular for malignant neoplasms of the oesophagus, stomach, and lung, although the mortality was also high for all men in this social class in the national population. Regional variations may have accounted for some of the high mortality. There were other raised mortality patterns in malignant neoplasms of the intestine, rectum, larynx, and prostate but these tended to be isolated and not consistent across refineries and other subgroups. As in the earlier follow up there was raised mortality from melanoma in several job groups.
\end{abstract}

(British fournal of Industrial Medicine 1993;50:549-560)

Department of Public Health Medicine and Epidemiology, University Hospital, Queen's Medical Centre, Nottingham, NG7 2UH L Rushton
Previous publications ${ }^{12}$ document the initial follow up from 1951 to 1975 of employees in eight United Kingdom oil refineries. This paper describes the results of extending this follow up to 31 December 1989. The detailed results for kidney cancer and leukaemia are reported elsewhere. ${ }^{3}$

Many studies have documented the carcinogenic properties of oil both in experimental ${ }^{45}$ and epidemiological studies. ${ }^{67}$ Others have investigated the carcinogenic and toxic properties of petroleum ${ }^{8}$ and its effect on the kidney. ${ }^{9}$

Several papers and unpublished reports have described past or ongoing studies of the mortality and less often the morbidity, of refinery populations. ${ }^{10-21}$ Four papers ${ }^{22-25}$ provide narrative epidemiological reviews. There is considerable variation in the dates, duration of follow up, and numbers in these studies. Those lost to follow up varies from $1 \%$ to $16 \%$. Most of the studies show the healthy worker effect ${ }^{26}$ to some extent, an effect that is reflected in many of the numerically large nonmalignant diseases such as respiratory and cardiovascular diseases.

Most of the papers have focused on malignant diseases. The mortality from all malignant diseases tended to be lower than expected. In several studies the significant deficit from all malignant diseases was mainly due to a significant deficit from cancer of the lung. ${ }^{13} 151927$ Smoking history is not usually available in these studies although there is some suggestion that oil refinery workers smoke less than comparable groups in other industries. ${ }^{28} \mathrm{By}$ contrast Bertazzi et al ${ }^{11}$ found a significant excess from lung cancer when Italy was used as a comparison population.

Bearing in mind the problems of small numbers of deaths and multiplicity of statistical tests several studies have found excesses in specific cancer sites. Increased mortality (albeit mainly statistically nonsignificant) has been found for the total study population or in subgroups for cancers of the liver, ${ }^{10} 1429$ pancreas, ${ }^{13} 14 \quad 30-32$ digestive system, ${ }^{16}$ stomach, ${ }^{14} 33$ intestines and rectum, ${ }^{34} 35$ prostate, ${ }^{21}$ 3031 kidney, 11133036 and brain, 10111314171920293033 and melanoma, 162729 and leukaemia. ${ }^{11-13} 19-213133$

A few studies of resident populations in areas where the petroleum industry is concentrated have 
suggested links between certain diseases and the industry..$^{37-39}$ As Harrington ${ }^{23}$ points out, however, these types of studies are at best hypothesis generating exercises and should therefore be interpreted with caution.

\section{Results of the Institute of Petroleum follow up study, 1951-75}

The overall mortality in the previously reported results for the Institute of Petroleum refinery follow up study to $1975^{1}$ was considerably lower than expected as was the mortality from heart disease, stroke, bronchitis, and pneumonia. The lowered mortality from all neoplasms was due to a large deficit of observed deaths from lung cancer. Raised mortality patterns were found in several refineries for cancers of the oesophagus, stomach, intestines, and rectum with significantly more deaths than expected from cancer of the nasal cavities and sinus and from melanoma.

\section{Methods}

Full details of the feasibility study carried out before the initial data collection, the reasoning behind the choice of data, items to be collected, and the methods used have been presented earlier. ${ }^{12}$ The study included all men with a duration of service of at least one continuous year between 1 January 1950 and 31 December 1975 at eight refineries in the United Kingdom. In this paper the refineries are denoted A, B, C, D, F, G, $\mathrm{H}$, and $\mathrm{J}$.

Data collected from personnel records comprised full name, date of birth, address, date of joining, last job (or present job for those in employment on 1 January 1976), whether a day or shift worker, National Insurance (NI) number and NHS number where available. For those who left before 1 January 1976 , date of leaving and the reason for leaving were also collected.

In the previous follow up a one off tracing exercise was carried out with the National Health Service Central Registers (NHSCRs) at Southport and Edinburgh for men for whom the NHS number was available or the Social Security records at Newcastle otherwise. Full details on death were obtained for all those found to be dead either directly from the NHSCRs or from the Office of Population Census and Surveys (OPCS).

In the study reported here it was decided to carry out a flagging procedure at the NHSCRs. Details of all the study population not dead at 31 December 1975 were sent to the NHSCRs who identified those who had since died and provided the death certificates. Also it was decided to flag the records for the others. This flagging procedure enables the NHSCRs to identify the study population who die in the future and to provide the details of death, a process that continues until the whole cohort dies. The death certificates provided multiple causes of death coded to the International Classification of Disease (ICD) revision in use at the time of death.

For those for whom the NHSCRs were unable to trace a death or general practitioner registration, details were sent to the Social Security records for one off tracing, from the NI number. For those identified as dead in this way a death certificate was then obtained.

When most of the flagging had been completed an examination of the records for those leaving before 1 January 1976 showed that of those flagged as alive at 31 December $1989,13 \%$ were aged over 70 compared with $9 \%$ over 70 in the population of England and Wales. As incorrect flagging as alive could have resulted from failure to link the death record to the NHS record, it was decided to trace all these men (about 4000) through the National Insurance records for further deaths. Evidence of the incompleteness of the NHSCR records, particularly in the elderly, has also been shown by Darby et al. ${ }^{40}$ As a result of this exercise a further 398 deaths that occurred before 1990 were identified.

Those who emigrated have been considered to be alive up to the date of emigration, this date therefore being their study end date. As all records were sent to the NHSCRs for flagging, more emigrations were identified than in the previous follow up in which much of the tracing was carried out through the National Insurance records, which do not identify emigrations.

As in the analysis of the first follow up, ${ }^{12}$ the expected deaths have been calculated by applying the five year age and calendar period specific death rates for England and Wales for the six English or Welsh refineries, and corresponding Scottish rates for the two Scottish refineries to the five year age and calendar period person-years at risk in the study cohort. Account was taken of the disparities between the four revisions of the ICD covered by the study period with standard bridging codes.

The standardised mortality ratio (SMR) was calculated from the ratio observed deaths: expected deaths multiplied by 100 . The $95 \%$ confidence interval $(95 \% \mathrm{CI})$ is given for each SMR.+1 No formal adjustment has been made to take account of known regional variations in death rates. These, together with variations in death rates by social class, have been used to aid the interpretation of the results.

Many of the problems and limitations inherent in the interpretation of the results from this type of study have been discussed previously. ${ }^{1} 2$ This is mainly an a posteriori study and the data should be used principally to generate hypotheses to be further investigated in other studies on new data. 
The study can, however, also be used as an a priori study to examine hypotheses suggested by other studies.

The use of hypothesis testing (leading to $\mathrm{p}$ values) is only strictly appropriate for the a priori approach. It is, however, widely and indiscriminately used in a posteriori epidemiological studies and can lead to a problem of multiple comparisons with the chance of producing a spurious statistically significant result in the absence of a real excess of mortality. ${ }^{42}$

As pointed out by Gardner and Altman ${ }^{41}$ undue emphasis on hypothesis testing in medical studies has led to studies aimed at reaching statistical significance rather than determining the magnitude of any effects of interest. A preferable approach to significance testing is to use confidence intervals to examine the magnitude and patterns of mortality in the data across different variables and subgroups ${ }^{41} 42$ rather than giving undue weight to isolated results.

In many industrial cohort studies of this type the overall SMR from all causes of death is found to be low-for example, around 90-and hence the cohort exhibits the healthy worker effect. ${ }^{26}$ Consideration needs to be given in these cases to the interpretation of the SMRs for specific causes (which may be greater than 100).

The impact of the reanalysis of data in a cohort study after a further 14 years of follow up also needs to be considered because repeated analysis of accruing data also leads to a multiplicity problem. Allowance for this may be made in various ways, most simply by the use of techniques such as repeated confidence intervals. ${ }^{43}$

\section{Results}

Table 1 shows the status of the study population at 31 December 1989. There were 34569 men in the study (compared with 34781 at 31 December 1975), 22600 alive, 10193 dead, 1691 emigrated, and 85 untraced. As before untraced men have not been included in the analyses. Included in the alive group were 723 men whom it was not possible to flag at the NHSCRs but who have been traced as

Table 1 Vital status of refinery study population at 31 December 1989

\begin{tabular}{lrrrrrr}
\hline Refinery & Alive & & Dead & Emigrated & No trace & Total \\
\cline { 1 - 4 } \cline { 5 - 7 } A & 1153 & & 439 & 117 & 9 & 1718 \\
B & 2825 & & 1480 & 277 & 40 & 4622 \\
C & 1606 & & 712 & 50 & 1 & 2369 \\
D & 2909 & & 1187 & 265 & 20 & 4381 \\
F & 2451 & & 1803 & 130 & 1 & 4385 \\
G & 182 & & 122 & 10 & 1 & 315 \\
H & 3540 & & 1191 & 299 & 1 & 5031 \\
J & 7934 & & 3259 & 543 & 12 & 11748 \\
Total & 22600 & 10193 & 1691 & 85 & 34569 \\
\hline
\end{tabular}

alive at 31 December 1989 through the National Insurance records.

The smaller refinery population at the second follow up is because during the flagging and the merging of the new data base created for this follow up with old data files some duplicate records were identified. During the flagging process a few extra deaths were also identified for the previous follow up period. These, combined with the slightly smaller study population, have slightly altered the results for 1951-75 presented in this paper compared with those previously published.

Those dead included 70 for whom it was not possible to obtain a death certificate, 26 who were known to have died abroad, and 44 who were identified as dead by the National Insurance records but for whom no trace was found either in the English or Scottish death certificate records or the company pension records. In the analyses these 70 men were taken as dead, cause unknown.

Table 2 shows the person-years of observation for each follow up period for the total study population and for each refinery; there was an increase of roughly 360000 person-years overall.

As described the information collected about job was the last job title for those who had left the refineries or the current title for those in post. Table 3 gives the distribution of the study population by job title. About a quarter of the total work-

Table 2 Person-years of observation of the refinery study population

\begin{tabular}{lcc}
\hline & \multicolumn{2}{c}{ Person-years of observation } \\
\cline { 2 - 3 } Refinery & At 31 December & $\begin{array}{l}\text { At } 31 \text { December } \\
1989\end{array}$ \\
\hline A & 45461 & 27439 \\
B & 127772 & 82772 \\
C & 59261 & 33857 \\
D & 114654 & 67684 \\
F & 119229 & 79361 \\
G & 9093 & 6351 \\
H & 140406 & 85405 \\
J & 315764 & 193114 \\
Total & 931640 & 575983 \\
\hline
\end{tabular}

Table 3 Refinery population by job classification

\begin{tabular}{lc}
\hline fob title & No $(\%)$ \\
\hline Operator & $9018(26 \cdot 1)$ \\
Maintenance & $8211(23 \cdot 8)$ \\
General labourer & $5098(14 \cdot 7)$ \\
Storeman & $480(1 \cdot 4)$ \\
Driver & $987(2 \cdot 9)$ \\
Fire and safety & $1046(3 \cdot 0)$ \\
Foreman & $2484(7 \cdot 2)$ \\
Scientific and technical & $2110(6 \cdot 1)$ \\
Administrative and clerical & $3438(9 \cdot 9)$ \\
Engineer & $1697(4 \cdot 9)$ \\
Total & $34569(100 \cdot 0)$ \\
\hline
\end{tabular}


force were operators and a further quarter were craftsmen (analysed separately as fitters, pipefitters, riggers, and others). About $15 \%$ were labourers and $10 \%$ administrative, clerical and managerial groups. The other subgroups analysed separately, such as drivers, fire and safety workers, and foremen, consisted of small numbers, leading to small numbers of deaths and the corresponding problems of interpretation. Analyses by seven years of entry groups, (pre-1940, 1940-9, 1950-4, 1955-9, 1960-4, 1965-9, 1970-4) also yielded small numbers for many disease groups making the patterns of mortality unclear. It should be noted that the study cohort is only complete for men joining after 1950 and before 1975 and staying for at least one year. Those that left before this date were excluded; this omission of shorter service workers starting before 1950 may thus have influenced the patterns of mortality.

Analyses by years since first employment $(0-9,10-19,20-29,30-39,40-49, \geqslant 50)$ are presented for selected causes. Time since first employment can be regarded as a proxy for duration of

Table 4 Observed (O) and expected (E) deaths, SMRs, and 95\% CIs for non-malignant causes of death

\begin{tabular}{|c|c|c|c|c|c|c|c|c|c|c|c|c|}
\hline \multirow[b]{2}{*}{ Causes of death } & \multicolumn{4}{|c|}{ Follow up 1951-75 } & \multicolumn{4}{|c|}{ Follow up 1976-89 } & \multicolumn{4}{|c|}{ Follow up 1951-89 } \\
\hline & $O$ & $E$ & $S M R$ & $(95 \% C I)$ & $O$ & $E$ & $S M R$ & $(95 \% C I)$ & $\bar{O}$ & $E$ & $S M R$ & $(95 \% C I)$ \\
\hline All causes & 4498 & $4981 \cdot 6$ & 90 & $(88-93)$ & 5695 & $6271 \cdot 8$ & 91 & $(88-93)$ & 10193 & $11253 \cdot 3$ & 91 & $(89-92)$ \\
\hline Respiratory TB & 25 & $55 \cdot 5$ & 45 & $(29-67)$ & 4 & $10 \cdot 2$ & 39 & $(11-100)$ & 29 & $65 \cdot 7$ & 44 & $(30-63)$ \\
\hline Diabetes & 17 & $29 \cdot 0$ & 59 & $(34-94)$ & 49 & $56 \cdot 2$ & 87 & $(65-115)$ & 66 & $85 \cdot 2$ & 77 & $(60-99)$ \\
\hline $\begin{array}{l}\text { Cerebrovascular } \\
\text { Disease }\end{array}$ & 417 & $439 \cdot 7$ & 95 & $(86-104)$ & 437 & $546 \cdot 6$ & 80 & $(73-88)$ & 854 & $986 \cdot 3$ & 87 & $(81-93)$ \\
\hline $\begin{array}{l}\text { Chronic rheumatic } \\
\text { heart disease }\end{array}$ & 54 & $69 \cdot 4$ & 78 & $(58-102)$ & 16 & $26 \cdot 1$ & 57 & $(32-95)$ & 70 & $95 \cdot 5$ & 73 & $(57-93)$ \\
\hline $\begin{array}{l}\text { Ischaemic heart } \\
\text { disease }\end{array}$ & 1443 & $1495 \cdot 8$ & 96 & $(92-102)$ & 1924 & $2125 \cdot 4$ & 91 & $(87-95)$ & 3367 & $3621 \cdot 2$ & 93 & $(90-96)$ \\
\hline $\begin{array}{l}\text { Other heart } \\
\text { disease }\end{array}$ & 90 & $107 \cdot 2$ & 84 & $(68-103)$ & 140 & $163 \cdot 3$ & 86 & $(72-101)$ & 230 & $270 \cdot 5$ & 85 & $(74-97)$ \\
\hline $\begin{array}{l}\text { Hypertensive heart } \\
\text { disease }\end{array}$ & 76 & 96.5 & 79 & $(62-99)$ & 34 & $51 \cdot 3$ & 66 & $(46-93)$ & 110 & $147 \cdot 8$ & 74 & $(61-90)$ \\
\hline $\begin{array}{l}\text { Diseases of the } \\
\text { arteries }\end{array}$ & 93 & $87 \cdot 5$ & 106 & $(86-130)$ & 205 & $160 \cdot 6$ & 128 & $(111-146)$ & 298 & $248 \cdot 1$ & 120 & $(107-135)$ \\
\hline $\begin{array}{l}\text { Other circulatory } \\
\text { disease }\end{array}$ & 39 & $37 \cdot 3$ & 105 & $(74-143)$ & 29 & $34 \cdot 1$ & 85 & $(56-122)$ & 68 & $71 \cdot 4$ & 95 & $(74-121)$ \\
\hline Pneumonia & 163 & $181 \cdot 2$ & 90 & $(77-105)$ & 228 & $269 \cdot 2$ & 85 & $(74-96)$ & 391 & $450 \cdot 4$ & 87 & $(78-96)$ \\
\hline $\begin{array}{l}\text { Bronchitis and } \\
\text { emphysema }\end{array}$ & 257 & $345 \cdot 4$ & 74 & $(66-84)$ & 168 & $234 \cdot 8$ & 72 & $(61-83)$ & 425 & $580 \cdot 2$ & 73 & $(66-81)$ \\
\hline Peptic ulcer & 52 & $53 \cdot 6$ & 97 & $(72-127)$ & 38 & $45 \cdot 7$ & 83 & $(59-114)$ & 90 & $99 \cdot 3$ & 91 & $(73-111)$ \\
\hline Cirrhosis of liver & 14 & $21 \cdot 4$ & 65 & $(36-110)$ & 24 & $37 \cdot 2$ & 65 & $(41-96)$ & 38 & $58 \cdot 6$ & 65 & $(46-89)$ \\
\hline $\begin{array}{l}\text { Nephritis and } \\
\text { nephrosis }\end{array}$ & 32 & $38 \cdot 3$ & 84 & $(57-118)$ & 7 & $9 \cdot 6$ & 73 & $(29-150)$ & 39 & $47 \cdot 9$ & 82 & $(58-111)$ \\
\hline $\begin{array}{l}\text { Hyperplasia of } \\
\text { prostate }\end{array}$ & 15 & $16 \cdot 1$ & 93 & $(52-154)$ & 13 & $11 \cdot 0$ & 118 & $(63-202)$ & 28 & $27 \cdot 1$ & 103 & $(69-149)$ \\
\hline $\begin{array}{l}\text { Motor vehicle } \\
\text { accidents }\end{array}$ & 110 & $104 \cdot 7$ & 105 & $(86-127)$ & 32 & $49 \cdot 8$ & 64 & $(44-91)$ & 142 & $154 \cdot 5$ & 92 & $(77-108)$ \\
\hline Accidental falls & 23 & $30 \cdot 1$ & 76 & $(48-115)$ & 27 & $29 \cdot 4$ & 92 & $(61-134)$ & 50 & $59 \cdot 5$ & 84 & $(62-111)$ \\
\hline $\begin{array}{l}\text { Accidental fire } \\
\text { and explosion }\end{array}$ & 12 & $5 \cdot 9$ & 203 & $(105-355)$ & 10 & $6 \cdot 1$ & 164 & $(79-301)$ & 22 & $12 \cdot 0$ & 183 & $(115-278)$ \\
\hline Suicide & 64 & 85.9 & 75 & $(57-95)$ & 43 & $58 \cdot 8$ & 73 & $(53-99)$ & 107 & $144 \cdot 7$ & 74 & $(61-89)$ \\
\hline
\end{tabular}

Table 5 Observed $(O)$ and expected $(E)$ deaths, SMRs and $95 \%$ CIs for selected causes by time since first employment

\begin{tabular}{|c|c|c|c|c|c|c|c|c|c|c|c|c|}
\hline \multirow[b]{3}{*}{ Disease } & \multicolumn{12}{|c|}{ Time Since First Employment (y) } \\
\hline & \multicolumn{4}{|l|}{$0-9$} & \multicolumn{4}{|l|}{$10-19$} & \multicolumn{4}{|l|}{$20-29$} \\
\hline & $O$ & $E$ & $S M R$ & $(95 \% C I)$ & $O$ & $E$ & $S M R$ & $(95 \% C I)$ & $O$ & $E$ & $S M R$ & $(95 \% C I)$ \\
\hline All causes & 559 & $721 \cdot 0$ & 78 & $(71-84)$ & 1585 & $1881 \cdot 3$ & 84 & $(80-89)$ & 2934 & $3194 \cdot 6$ & 92 & $(86-95)$ \\
\hline All neoplasms & 154 & $165 \cdot 7$ & 92 & $(79-109)$ & 446 & $486 \cdot 7$ & 92 & $(83-101)$ & 854 & $866 \cdot 8$ & 99 & $(92-105)$ \\
\hline $\begin{array}{l}\text { Malignant neoplasm } \\
\text { of stomach }\end{array}$ & 24 & $19 \cdot 9$ & 121 & $(77-180)$ & 61 & $55 \cdot 5$ & 110 & $(84-141)$ & 94 & $86 \cdot 7$ & 108 & $(88-133)$ \\
\hline Intestine & 10 & $9 \cdot 7$ & 103 & $(50-190)$ & 29 & $29 \cdot 9$ & 97 & $(65-139)$ & 45 & $54 \cdot 8$ & 82 & $(60-110)$ \\
\hline Rectum & 6 & $6 \cdot 7$ & 90 & $(33-195)$ & 18 & $21 \cdot 2$ & 85 & $(50-134)$ & 39 & $39 \cdot 2$ & 99 & $(71-136)$ \\
\hline Lung & 46 & $58 \cdot 4$ & 79 & $(58-105)$ & 157 & $196 \cdot 8$ & 80 & $(68-93)$ & 349 & $356 \cdot 7$ & 98 & $(88-109)$ \\
\hline Prostate & 3 & $2 \cdot 2$ & 136 & $(28-396)$ & 10 & $12 \cdot 6$ & 79 & $(38-146)$ & 44 & $38 \cdot 8$ & 113 & $(82-152)$ \\
\hline Melanoma & 8 & $1 \cdot 7$ & 467 & (202-920) & 9 & $3 \cdot 9$ & 230 & $(105-437)$ & 8 & $5 \cdot 3$ & 151 & $(65-298)$ \\
\hline Leukaemia & 10 & $7 \cdot 6$ & 132 & $(63-242)$ & 13 & $13 \cdot 5$ & 96 & $(51-165)$ & 19 & $19 \cdot 1$ & 99 & $(60-155)$ \\
\hline Cerebrovascular disease & 28 & $42 \cdot 7$ & 66 & $(44-95)$ & 119 & $141 \cdot 7$ & 84 & $(70-101)$ & 242 & $265 \cdot 2$ & 91 & $(80-104)$ \\
\hline $\begin{array}{l}\text { Ischaemic heart disease } \\
\text { disease }\end{array}$ & 140 & $158 \cdot 7$ & 88 & $(74-104)$ & 487 & $584 \cdot 8$ & 83 & $(76-91)$ & 1031 & $1100 \cdot 0$ & 94 & $(88-100)$ \\
\hline Diseases of the arteries & 4 & $6 \cdot 0$ & 67 & $(18-172)$ & 20 & $26 \cdot 1$ & 77 & $(47-118)$ & 78 & $65 \cdot 6$ & 119 & $(94-148)$ \\
\hline Pneumonia & 8 & $17 \cdot 0$ & 47 & $(20-93)$ & 34 & $53 \cdot 4$ & 64 & $(44-89)$ & 121 & $119 \cdot 5$ & 101 & $(84-121)$ \\
\hline Bronchitis & 8 & $31 \cdot 7$ & 25 & $(11-50)$ & 88 & $109 \cdot 4$ & 80 & $(64-99)$ & 132 & $171 \cdot 1$ & 77 & $(65-92)$ \\
\hline
\end{tabular}


exposure, although it was not possible to collect data on actual exposures to the multiplicity of chemicals and other potential hazards in an oil refinery for the total duration of the follow up.

\section{NON-MALIGNANT CAUSES OF DEATH}

Table 4 gives the observed and expected deaths, SMRs, and $95 \%$ CIs for the SMRs by non-malignant causes of death for the total refinery study population. These are presented separately for the first follow up, the second follow up, and the total follow up period.

The SMRs for all causes of death were similar for the two follow up periods, indicative of a continuation of the healthy worker effect. For many of the numerically large non-malignant causes of death, such as cerebrovascular disease, ischaemic heart disease, and pneumonia, the SMR for the second follow up period was lower than that of the first period. For other disease groups, such as bronchitis and cirrhosis of the liver, the SMRs for the two follow up periods were similar. A clear exception to this was diseases of the arteries where the SMR for the later follow up period was much larger than that of the first period.

The total follow up period results showed large deficits of observed deaths compared with expected deaths for the total study population for all causes, and many of the other disease groups. Only diseases of the arteries and accidental fire and explosion were clearly raised (as judged by the confidence interval).

The SMRs for all causes of death were very low for all the refineries with the exception of refinery $\mathrm{F}$, where the observed deaths roughly equalled those expected. Mortality from all causes was also low for both shift and day workers and across all job groups except fire and safety workers, drivers, and storemen in whom the observed deaths roughly equalled those expected, and labourers in whom mortality was raised by about $10 \%$. Table 5 gives the observed and expected deaths, SMRs and 95\% CIs by time since first employment for selected causes of death. There was a tendency for the all cause mortality to increase with increasing time since first employment and earlier year of entry.

Many of the numerically large non-malignant disease groups such as ischaemic heart disease, other heart disease, cerebrovascular disease, and pneumonia, showed the same patterns of mortality as the all cause mortality. Most of the job groups also had low mortality from these disease groups, with slightly higher mortality in fire and safety workers, drivers, and storemen.

Labourers, however, showed raised mortality both overall and from several disease groups. Table 6 gives the observed and expected deaths, SMRs and $95 \%$ CIs for labourers for several disease and refinery subgroups. The mortality from both all causes of death and all neoplasms was clearly raised both for the total labourer population and at several refineries. Similar patterns were found for several of the non-malignant disease groups-for example, cerebrovascular disease, ischaemic heart disease (though not pronounced), diseases of the arteries, other diseases of the circulatory system, pneumonia, and bronchitis and emphysema.

There were a few increases in mortality over expected numbers in some refinery and non-malignant cause of death combinations. Most of these were due to a corresponding increase in mortality in labourers-for example, this was true for ischaemic heart disease at refinery $F(O=595$, $\mathrm{E}=554 \cdot 4, \mathrm{SMR}=107,95 \% \mathrm{CI} 99-116)$ and pneumonia at refinery $\mathrm{J}(\mathrm{O}=166, \mathrm{E}=135.4$, $\mathrm{SMR}=123,95 \%$ CI 105-143).

An overall appreciable excess of observed deaths compared with those expected was found for accidental fire and explosion, (see table 4 ), especially at refinery $\mathrm{F}(\mathrm{O}=10, \mathrm{E}=1 \cdot 6, \mathrm{SMR}=641,95 \% \mathrm{CI}$ 307-1179) and refinery $\mathrm{J}(\mathrm{O}=9, \mathrm{E}=3.4$, $\mathrm{SMR}=262,95 \%$ CI 120-498). These deaths

\begin{tabular}{|c|c|c|c|c|c|c|c|c|c|c|c|}
\hline \multicolumn{4}{|l|}{$30-39$} & \multicolumn{4}{|l|}{$40-49$} & \multicolumn{4}{|l|}{$\geqslant 50$} \\
\hline$O$ & $E$ & $S M R$ & $(95 \% C I)$ & $O$ & $E$ & $S M R$ & $(95 \% C I)$ & $O$ & $E$ & $S M R$ & $(95 \% C I)$ \\
\hline $\begin{array}{r}3081 \\
826 \\
-\quad 74\end{array}$ & $\begin{array}{r}3242 \cdot 6 \\
895 \cdot 1 \\
83 \cdot 0\end{array}$ & $\begin{array}{l}95 \\
92 \\
89\end{array}$ & $\begin{array}{l}(92-98) \\
(86-99) \\
(70-112)\end{array}$ & $\begin{array}{r}1288 \\
320 \\
33\end{array}$ & $\begin{array}{r}1388 \cdot 3 \\
354 \cdot 6 \\
34 \cdot 4\end{array}$ & $\begin{array}{l}93 \\
90 \\
96\end{array}$ & $\begin{array}{l}(88-99) \\
(80-100) \\
(66-135)\end{array}$ & $\begin{array}{r}746 \\
173 \\
16\end{array}$ & $\begin{array}{r}824 \cdot 8 \\
180.9 \\
16.9\end{array}$ & $\begin{array}{l}90 \\
96 \\
94\end{array}$ & $\begin{array}{l}(84-97) \\
(82-111) \\
(54-153)\end{array}$ \\
\hline $\begin{array}{r}70 \\
37 \\
305 \\
55 \\
4 \\
19 \\
.266 \\
1059\end{array}$ & $\begin{array}{r}58 \cdot 8 \\
40 \cdot 3 \\
351 \cdot 8 \\
60 \cdot 0 \\
4 \cdot 2 \\
18 \cdot 5 \\
291 \cdot 7 \\
1091 \cdot 0\end{array}$ & $\begin{array}{r}119 \\
92 \\
87 \\
92 \\
95 \\
103 \\
91 \\
97\end{array}$ & $\begin{array}{l}(93-150) \\
(65-127) \\
(77-97) \\
(69-119) \\
(26-243) \\
(62-161) \\
(81-103) \\
(91-103)\end{array}$ & $\begin{array}{r}20 \\
16 \\
100 \\
38 \\
1 \\
5 \\
116 \\
423\end{array}$ & $\begin{array}{r}23 \cdot 8 \\
16 \cdot 2 \\
138 \cdot 0 \\
29 \cdot 0 \\
1 \cdot 2 \\
7 \cdot 2 \\
143 \cdot 8 \\
444 \cdot 1\end{array}$ & $\begin{array}{r}84 \\
99 \\
72 \\
131 \\
81 \\
69 \\
81 \\
95\end{array}$ & $\begin{array}{l}(51-130) \\
(56-160) \\
(59-88) \\
(93-180) \\
(2-452) \\
(23-162) \\
(67-97) \\
(86-105)\end{array}$ & $\begin{array}{r}12 \\
10 \\
62 \\
21 \\
0 \\
2 \\
83 \\
227\end{array}$ & $\begin{array}{r}13 \cdot 3 \\
8 \cdot 6 \\
64 \cdot 6 \\
20 \cdot 2 \\
0 \cdot 5 \\
3 \cdot 9 \\
101 \cdot 2 \\
242 \cdot 6\end{array}$ & $\begin{array}{r}90 \\
116 \\
96 \\
104 \\
0 \\
51 \\
82 \\
94\end{array}$ & $\begin{array}{r}(47-158) \\
(56-213) \\
(74-123) \\
(64-159) \\
(0-738) \\
(6-159) \\
(65-102) \\
(82-107)\end{array}$ \\
\hline $\begin{array}{r}107 \\
123 \\
112\end{array}$ & $\begin{array}{r}82 \cdot 5 \\
128 \cdot 0 \\
148 \cdot 5\end{array}$ & $\begin{array}{r}130 \\
96 \\
75\end{array}$ & $\begin{array}{c}(106-157) \\
(80-115) \\
(62-91)\end{array}$ & $\begin{array}{l}54 \\
57 \\
60\end{array}$ & $\begin{array}{l}39 \cdot 7 \\
69 \cdot 2 \\
76 \cdot 2\end{array}$ & $\begin{array}{r}136 \\
82 \\
79\end{array}$ & $\begin{array}{r}(102-177) \\
(62-107) \\
(60-101)\end{array}$ & $\begin{array}{l}35 \\
48 \\
25\end{array}$ & $\begin{array}{l}28 \cdot 2 \\
63 \cdot 3 \\
43 \cdot 3\end{array}$ & $\begin{array}{r}124 \\
76 \\
58\end{array}$ & $\begin{array}{l}(86-172) \\
(56-100) \\
(37-85)\end{array}$ \\
\hline
\end{tabular}


Table 6 Observed $(O)$ and expected deaths, SMRs, and 95\% CIs for labourers for selected disease and refinery subgroups

\begin{tabular}{|c|c|c|c|c|c|}
\hline Disease & Refinery & $O$ & $E$ & $S M R$ & $(95 \% C I)$ \\
\hline \multirow[t]{9}{*}{ All causes } & A & 83 & 99.9 & 83 & $(66-103)$ \\
\hline & $\mathrm{B}$ & 288 & $320 \cdot 4$ & 90 & $(80-101)$ \\
\hline & C & 269 & $256 \cdot 4$ & 105 & (93-118) \\
\hline & $\mathrm{D}$ & 232 & $208 \cdot 0$ & 112 & $(98-127)$ \\
\hline & $\mathrm{F}$ & 644 & $536 \cdot 0$ & 120 & $(111-130)$ \\
\hline & G & 16 & $14 \cdot 3$ & 112 & (64-182) \\
\hline & $\mathrm{H}$ & 174 & $162 \cdot 8$ & 107 & $(92-124)$ \\
\hline & $J$ & 708 & $620 \cdot 3$ & 114 & $(106-123)$ \\
\hline & Total & 2414 & $2217 \cdot 9$ & 109 & (105-113) \\
\hline \multirow[t]{4}{*}{ All neoplasms } & $\mathrm{D}$ & 63 & $54 \cdot 5$ & 116 & $(89-148)$ \\
\hline & $\mathrm{F}$ & 139 & $129 \cdot 3$ & 108 & $(90-127)$ \\
\hline & $\mathrm{J}$ & 200 & $158 \cdot 6$ & 126 & $(109-145)$ \\
\hline & Total & 609 & $557 \cdot 8$ & 109 & $(101-118)$ \\
\hline \multirow{4}{*}{$\begin{array}{l}\text { Malignant } \\
\text { neoplasm of } \\
\text { stomach }\end{array}$} & $\mathrm{D}$ & 12 & $5 \cdot 6$ & 215 & $(111-378)$ \\
\hline & $\mathrm{F}$ & 26 & $15 \cdot 0$ & 173 & $(113-254)$ \\
\hline & $\mathrm{J}$ & 34 & $17 \cdot 0$ & 201 & (139-280) \\
\hline & Total & 88 & 59.9 & 147 & (118-181) \\
\hline $\begin{array}{l}\text { Malignant } \\
\text { neoplasm of } \\
\text { lung }\end{array}$ & Total & 254 & $221 \cdot 3$ & 115 & $(101-130)$ \\
\hline Malignant & Total & 24 & $16 \cdot 8$ & 143 & $(92-213)$ \\
\hline $\begin{array}{l}\text { neoplasm of } \\
\text { oesophagus }\end{array}$ & & & & & \\
\hline \multirow{2}{*}{$\begin{array}{l}\text { Cerebrovascular } \\
\text { disease: }\end{array}$} & $\mathrm{J}$ & 73 & $57 \cdot 3$ & 127 & $(100-160)$ \\
\hline & Total & 221 & $214 \cdot 9$ & 103 & $(90-117)$ \\
\hline $\begin{array}{l}\text { Ischaemic heart } \\
\text { disease }\end{array}$ & $\mathrm{F}$ & 186 & $162 \cdot 4$ & 115 & $(99-132)$ \\
\hline \multirow{2}{*}{$\begin{array}{l}\text { Diseases of the } \\
\text { arteries }\end{array}$} & $\mathrm{F}$ & 27 & $13 \cdot 7$ & 198 & $(130-288)$ \\
\hline & Total & 64 & $52 \cdot 0$ & 123 & $(95-157)$ \\
\hline $\begin{array}{l}\text { Other circulatory } \\
\text { diseases }\end{array}$ & Total & 22 & $14 \cdot 5$ & 152 & $(95-230)$ \\
\hline \multirow[t]{2}{*}{ Pneumonia } & $\mathrm{J}$ & 51 & $28 \cdot 0$ & 182 & $(136-240)$ \\
\hline & Total & 121 & $101 \cdot 8$ & 119 & $(99-142)$ \\
\hline \multirow{2}{*}{$\begin{array}{c}\text { Bronchitis and } \\
\text { emphysema }\end{array}$} & $\mathrm{F}$ & 61 & $36 \cdot 9$ & 166 & $(127-213)$ \\
\hline & Total & 166 & $131 \cdot 9$ & 126 & $(107-147)$ \\
\hline
\end{tabular}

occurred mainly in operators overall $(\mathrm{O}=11$, $\mathrm{E}=3 \cdot 0, \mathrm{SMR}=364,95 \% \mathrm{CI} 182-652)$, and, at refinery $F$, in other craftsmen $(\mathrm{O}=3, \mathrm{E}=0.15$, $\mathrm{SMR}=2037,95 \%$ CI 420-5954) and pipefitters $(\mathrm{O}=3, \mathrm{E}=0 \cdot 4, \mathrm{SMR}=731,95 \% \mathrm{CI} 151-2135)$.

The only large non-malignant disease group to show consistently raised mortality across several refineries and many of the other subgroups analysed was diseases of the arteries (ICD-9th revision 440-448). Table 7 summarises the results for this disease group. The mortality increased in the second follow up period and was much increased for every five year age group after 60 with the exception of the over 85 group. Three refineries and several job groups showed increased mortality from diseases of the arteries and there was a pronounced trend for increasing mortality with increasing time since first employment (see table 5).

Of the 298 deaths from the broad disease category, diseases of the arteries, 73 were from atherosclerosis $(E=70 \cdot 6, \quad S M R=103,95 \% \quad C I$ 81-130) and 187 were from aortic aneurysm. Table 8 summarises the results for aortic aneurysm.
Table 7 Observed (O) and expected (E) deaths, SMRs, and $95 \%$ CIs for diseases of the arteries by refinery and other subgroups

\begin{tabular}{|c|c|c|c|c|}
\hline Subgroup & $O$ & $E$ & $S M R$ & $(95 \% C I)$ \\
\hline \multicolumn{5}{|l|}{ Refinery: } \\
\hline A & 9 & $11 \cdot 1$ & 81 & $(37-154)$ \\
\hline B & 45 & $41 \cdot 5$ & 108 & $(79-145)$ \\
\hline $\mathrm{C}$ & 14 & $13 \cdot 8$ & 102 & $(56-170)$ \\
\hline $\mathrm{D}$ & 40 & $27 \cdot 7$ & 145 & (103-197) \\
\hline $\mathrm{F}$ & 65 & $43 \cdot 8$ & 148 & (115-189) \\
\hline G & 3 & $2 \cdot 9$ & 105 & $(22-306)$ \\
\hline $\mathrm{H}$ & 43 & $31 \cdot 7$ & 136 & $(98-183)$ \\
\hline $\mathrm{J}$ & 79 & $75 \cdot 6$ & 104 & $(83-130)$ \\
\hline \multicolumn{5}{|l|}{ Age: } \\
\hline$<60$ & 31 & $37 \cdot 8$ & 82 & $(56-116)$ \\
\hline $60-64$ & 40 & $31 \cdot 2$ & 128 & $(92-175)$ \\
\hline $65-69$ & 54 & $43 \cdot 8$ & 123 & $(93-161)$ \\
\hline $70-74$ & 69 & $50 \cdot 0$ & 138 & $(107-175)$ \\
\hline $75-79$ & 55 & $42 \cdot 6$ & 129 & $(97-168)$ \\
\hline $80-84$ & 34 & $27 \cdot 1$ & 125 & $(87-175)$ \\
\hline$>85$ & 15 & $15 \cdot 6$ & 96 & $(54-159)$ \\
\hline \multicolumn{5}{|l|}{ Job: } \\
\hline Operator & 58 & $56 \cdot 5$ & 103 & $(78-113)$ \\
\hline Fitter & 22 & $12 \cdot 2$ & 181 & (113-274) \\
\hline Pipefitter & 7 & 9.9 & 71 & $(28-146)$ \\
\hline Rigger & 6 & $5 \cdot 1$ & 117 & $(43-255)$ \\
\hline Other craftsman & 20 & $19 \cdot 7$ & 102 & $(62-157)$ \\
\hline Labourer & 64 & $52 \cdot 0$ & 123 & $(95-157)$ \\
\hline Storeman & 8 & $5 \cdot 5$ & 147 & (63-289) \\
\hline Driver & 13 & $7 \cdot 4$ & 175 & $(93-299)$ \\
\hline Fire and safety & 16 & $12 \cdot 7$ & 126 & $(72-206)$ \\
\hline Foreman & 32 & $24 \cdot 5$ & 131 & $(89-184)$ \\
\hline Scientific and technical & 5 & $6 \cdot 8$ & 73 & $(24-171)$ \\
\hline $\begin{array}{l}\text { Administrator/clerical } \\
\text { managerial }\end{array}$ & 34 & $26 \cdot 8$ & 127 & $(88-178)$ \\
\hline Engineer & 13 & $8 \cdot 9$ & 146 & $(78-250)$ \\
\hline
\end{tabular}

Mortality from aortic aneurysm was high in four of the eight refineries and accounted for the raised mortality from diseases of the arteries. The same job groups that showed raised mortality from diseases of the arteries showed raised mortality from aortic aneurysm. Only one refinery, F, showed raised mortality from atherosclerosis $(\mathrm{O}=27$, $\mathrm{E}=16 \cdot 9, \mathrm{SMR}=159,95 \% \mathrm{CI} 105-232)$.

\section{CAUSES OF DEATH FROM MALIGNANT DISEASES}

Table 9 gives the observed and expected deaths, the SMRs, and the $95 \%$ CIs for the SMRs by malignant causes of death for the total refinery study population. These are presented separately for the first follow up, the second follow up, and the total follow up periods.

The SMRs for the two follow up periods for all neoplasms were identical and many of the malignant subgroups showed a decreased SMR in the second period-namely, malignant neoplasms of the oesophagus, stomach, intestine, rectum, liver and gall bladder, pancreas, and larynx, and melanoma. The opposite trend was seen for malignant neoplasms of the lung and pleura, bladder, and brain, whereas the SMRs for malignant neoplasm of the prostate were identical for the two periods and those for leukaemia similar. There 
Table 8 Observed $(O)$ and expected $(E)$ deaths, SMRs, and 95\% CIs for aortic aneurysm by refinery and other subgroups

\begin{tabular}{lrrrr}
\hline Subgroup & $O$ & $E$ & $S M R$ & $(95 \% C I)$ \\
\hline Refinery: & & & & \\
A & 7 & $6 \cdot 6$ & 106 & $(43-218)$ \\
B & 27 & $23 \cdot 0$ & 117 & $(77-171)$ \\
C & 5 & $8 \cdot 1$ & 61 & $(20-143)$ \\
D & 26 & $16 \cdot 8$ & 154 & $(101-226)$ \\
F & 29 & $20 \cdot 4$ & 143 & $(95-205)$ \\
G & 0 & $1 \cdot 7$ & 0 & $(0-220)$ \\
H & 34 & $17 \cdot 7$ & 192 & $(133-268)$ \\
J & 59 & $41 \cdot 6$ & 142 & $(108-159)$ \\
Total & 187 & $135 \cdot 9$ & 138 & $(119-159)$ \\
Age: & & & & \\
<60 & 22 & $22 \cdot 2$ & 99 & $(62-150)$ \\
60-64 & 31 & $20 \cdot 4$ & 152 & $(103-216)$ \\
65-69 & 35 & $29 \cdot 2$ & 120 & $(83-167)$ \\
70-74 & 51 & $29 \cdot 5$ & 173 & $(129-227)$ \\
75-79 & 34 & $21 \cdot 8$ & 156 & $(108-218)$ \\
> 80 & 14 & $14 \cdot 1$ & 99 & $(54-166)$ \\
Job: & & & & \\
Operator & 34 & $32 \cdot 8$ & 104 & $(72-145)$ \\
Fitter & 15 & $6 \cdot 7$ & 226 & $(126-372)$ \\
Pipefitter & 4 & $5 \cdot 6$ & 71 & $(19-183)$ \\
Rigger & 3 & $2 \cdot 9$ & 103 & $(21-302)$ \\
Other craftsman & 14 & $11 \cdot 2$ & 125 & $(68-210)$ \\
Labourer & 30 & $25 \cdot 7$ & 117 & $(79-167)$ \\
Storeman & 6 & $2 \cdot 8$ & 214 & $(79-466)$ \\
Driver & 9 & $4 \cdot 3$ & 210 & $(96-399)$ \\
Fire and safety & 11 & $6 \cdot 2$ & 177 & $(89-317)$ \\
Foreman & 21 & $13 \cdot 6$ & 154 & $(95-235)$ \\
Scientific and technical & 5 & $5 \cdot 0$ & 100 & $(32-233)$ \\
Administrator/clerical/ & 24 & $14 \cdot 9$ & 162 & $(103-240)$ \\
$\quad$ managerial & & & & \\
Engineer & 11 & $4 \cdot 9$ & 224 & $(112-402)$ \\
\hline & & & & \\
\hline & & &
\end{tabular}

were no further deaths from malignant neoplasms of the nasal cavities and sinus in the second follow up period.

Examination of the results in table 9 for the total follow up period showed large deficits of observed deaths compared with expected deaths for the total study population for all neoplasms, malignant neoplasms of the buccal cavity and pharynx, and malignant neoplasms of the trachea, bronchus, and lung. There were a few SMRs greater than 100 for the total follow up period, but of these only melanoma was clearly increased.

Although the total number of observed deaths from all neoplasms was much fewer than those expected, three refineries (A, D, and J) had nearly the same observed deaths as expected. There was also a clear increase of about $10 \%$ in mortality from all neoplasms for labourers (see table 6).

\section{Malignant neoplasms of the digestive tract}

All these disease groups showed a tendency for a lower mortality in the second follow up period, (see table 9). Slightly increased mortality was found for malignant neoplasms of the oesophagus, especially at refinery $\mathrm{D}(\mathrm{O}=18, \mathrm{E}=11.4, \mathrm{SMR}=158,95 \%$ CI 93-249), and for malignant neoplasms of the stomach, especially at refineries $\mathrm{F}(\mathrm{O}=56$, $\mathrm{E}=48 \cdot 7, \quad \mathrm{SMR}=115,95 \% \mathrm{CI} 87-149)$ and $\mathrm{J}$ $(\mathrm{O}=111, \mathrm{E}=91 \cdot 2, \mathrm{SMR}=122,95 \%$ CI $100-147)$. There was raised mortality of over $40 \%$ overall for labourers in these two disease groups (see table 6), with excesses from malignant neoplasms of the stomach for labourers at refineries D, F, and J. Operators also showed raised mortality from malignant neoplasms of the oesophagus $(\mathrm{O}=32$, $\mathrm{E}=23 \cdot 0, \mathrm{SMR}=139,95 \% \mathrm{CI} 95-197)$ and stomach $(\mathrm{O}=82, \mathrm{E}=70 \cdot 5, \mathrm{SMR}=116,95 \%$ CI 93-144).

Table 9 Observed (O) and expected (E) deaths, SMRs, and 95\% CIs for malignant causes of death

\begin{tabular}{|c|c|c|c|c|c|c|c|c|c|c|c|c|}
\hline \multirow[b]{2}{*}{ Disease } & \multicolumn{4}{|c|}{ Follow up 1951-75 } & \multicolumn{4}{|c|}{ Follow up 1976-89 } & \multicolumn{4}{|c|}{ Follow up 1951-89 } \\
\hline & $O$ & $E$ & $S M R$ & $(95 \% C I)$ & $O$ & $E$ & $S M R$ & $(95 \% C I)$ & $O$ & $E$ & $S M R$ & $(95 \% C I)$ \\
\hline All neoplasms & 1163 & $1234 \cdot 6$ & 94 & $(89-100)$ & 1610 & $1715 \cdot 2$ & 94 & $(89-99)$ & 2773 & $2949 \cdot 8$ & 94 & $(91-98)$ \\
\hline $\begin{array}{l}\text { Malignant } \\
\text { neoplasm of } \\
\text { buccal cavity } \\
\text { and pharynx }\end{array}$ & 9 & $18 \cdot 4$ & 49 & $(22-93)$ & 15 & $26 \cdot 0$ & 58 & $(32-95)$ & 24 & $44 \cdot 4$ & 54 & $(35-80)$ \\
\hline Oesophagus & 37 & $30 \cdot 2$ & 123 & $(86-169)$ & 67 & $62 \cdot 3$ & 108 & $(83-137)$ & 104 & $92 \cdot 5$ & 112 & $(92-136)$ \\
\hline Intestine & 84 & $77 \cdot 0$ & 109 & $(87-135)$ & 102 & $113 \cdot 3$ & 90 & $(73-109)$ & 186 & $190 \cdot 3$ & 98 & $(84-113)$ \\
\hline Rectum & 59 & $55 \cdot 9$ & 106 & $(80-136)$ & 67 & $76 \cdot 4$ & 88 & $(68-111)$ & 126 & $132 \cdot 3$ & 95 & $(76-113)$ \\
\hline Gall bladder & 25 & $22 \cdot 5$ & 111 & $(72-164)$ & 22 & $27 \cdot 0$ & 81 & $(51-123)$ & 47 & $49 \cdot 5$ & 95 & $(70-126)$ \\
\hline Pancreas & 50 & $49 \cdot 9$ & 100 & $(74-132)$ & 60 & $73 \cdot 2$ & 82 & $(63-106)$ & 110 & $123 \cdot 1$ & 89 & $(73-108)$ \\
\hline Larynx & 13 & $12 \cdot 1$ & 107 & $(57-184)$ & 13 & $16 \cdot 1$ & 81 & $(43-138)$ & 26 & $28 \cdot 2$ & 92 & $(60-135)$ \\
\hline Lung and pleura & 421 & $508 \cdot 3$ & 83 & $(75-91)$ & 611 & $658 \cdot 0$ & 93 & $(86-101)$ & 1032 & $1166 \cdot 3$ & 88 & $(83-94)$ \\
\hline Prostate & 48 & $45 \cdot 8$ & 105 & $(77-139)$ & 123 & $117 \cdot 1$ & 105 & $(87-125)$ & 171 & 162.9 & 105 & $(90-122)$ \\
\hline Bladder & 34 & $42 \cdot 9$ & 79 & $(55-111)$ & 64 & $67 \cdot 5$ & 95 & $(73-121)$ & 98 & $110 \cdot 4$ & 89 & $(72-108)$ \\
\hline Kidney & 23 & $21 \cdot 5$ & 107 & $(68-161)$ & 33 & $33 \cdot 8$ & 98 & $(67-137)$ & 56 & $55 \cdot 3$ & 101 & $(77-132)$ \\
\hline Melanoma & 14 & $6 \cdot 4$ & 219 & $(120-367)$ & 16 & 10.5 & 152 & $(87-247)$ & 30 & $16 \cdot 9$ & 178 & $(120-254)$ \\
\hline $\begin{array}{l}\text { Reticulum cell } \\
\text { sarcoma }\end{array}$ & 5 & $7 \cdot 8$ & 64 & $(21-150)$ & 1 & $1 \cdot 6$ & 63 & $(2-348)$ & 6 & $9 \cdot 4$ & 64 & $(23-139)$ \\
\hline Lymphosarcoma & 11 & $8 \cdot 2$ & 134 & $(67-240)$ & 7 & $4 \cdot 4$ & 159 & $(64-328)$ & 18 & $12 \cdot 6$ & 143 & $(85-226)$ \\
\hline Hodgkin's disease & 13 & $16 \cdot 4$ & 79 & $(42-136)$ & 4 & $7 \cdot 0$ & 57 & $(16-146)$ & 17 & $23 \cdot 4$ & 73 & $(42-116)$ \\
\hline $\begin{array}{l}\text { Other neoplasms } \\
\text { of the lymphoid } \\
\text { tissue }\end{array}$ & 4 & $4 \cdot 3$ & 93 & $(25-238)$ & 23 & $27 \cdot 4$ & 84 & $(53-126)$ & 27 & $31 \cdot 7$ & 85 & $(56-124)$ \\
\hline Multiple myeloma & 11 & $10 \cdot 2$ & 108 & $(54-193)$ & 15 & $21 \cdot 8$ & 69 & $(39-113)$ & 26 & $32 \cdot 0$ & 81 & $(53-119)$ \\
\hline Leukaemia & 30 & $31 \cdot 2$ & 96 & $(65-137)$ & 38 & $38 \cdot 6$ & 98 & $(70-135)$ & 68 & $69 \cdot 8$ & 97 & $(76-124)$ \\
\hline
\end{tabular}


Table 10 Observed (O) and expected (E) deaths, SMRs, and $95 \%$ CIs for melanoma, by refinery and other subgroups

\begin{tabular}{lrlrc}
\hline Subgroup & $O$ & $E$ & $S M R$ & $(95 \% C I)$ \\
\hline Refinery: & & & & \\
A & 2 & $0 \cdot 88$ & 228 & $(28-825)$ \\
B & 5 & $2 \cdot 5$ & 202 & $(66-471)$ \\
C & 3 & $1 \cdot 0$ & 287 & $(59-839)$ \\
D & 1 & $2 \cdot 2$ & 45 & $(1-252)$ \\
F & 2 & $2 \cdot 1$ & 94 & $(11-341)$ \\
G & 0 & $0 \cdot 2$ & 0 & $(0-2052)$ \\
H & 11 & $2 \cdot 5$ & 444 & $(222-795)$ \\
J & 6 & $5 \cdot 5$ & 109 & $(40-238)$ \\
Total & 30 & $16 \cdot 9$ & 178 & $(120-254)$ \\
Job: & & & & \\
Operator & 10 & $4 \cdot 4$ & 227 & $(109-418)$ \\
Fitter & 1 & $0 \cdot 9$ & 110 & $(3-613)$ \\
Pipefitter & 1 & $0 \cdot 7$ & 150 & $(4-837)$ \\
Rigger & 0 & $0 \cdot 4$ & 0 & $(0-922)$ \\
Other craftsman & 4 & $1 \cdot 6$ & 245 & $(67-627)$ \\
Labourer & 3 & $2 \cdot 6$ & 117 & $(24-343)$ \\
Storeman & 0 & $0 \cdot 3$ & 0 & $(0-1230)$ \\
Driver & 1 & $0 \cdot 53$ & 188 & $(5-1048)$ \\
Fire and safety & 0 & $0 \cdot 5$ & 0 & $(0-738)$ \\
Foreman & 1 & $1 \cdot 5$. & 68 & $(2-379)$ \\
Scientific and technical & 0 & $0 \cdot 9$ & 0 & $(0-410)$ \\
Administrative/clerical/ & 7 & $1 \cdot 8$ & 390 & $(157-803)$ \\
$\quad$ managerial & & & & \\
Engineer & 2 & $0 \cdot 8$ & 253 & $(31-914)$ \\
\hline
\end{tabular}

Malignant neoplasms of the intestine, rectum, liver and gall bladder, and pancreas showed slightly lowered mortality overall although there was raised mortality at refinery $\mathrm{F}$ from malignant neoplasms of the rectum $(\mathrm{O}=32, \mathrm{E}=21 \cdot 3, \mathrm{SMR}=150,95 \% \mathrm{CI}$ 115-189); this excess was spread across many of the job groups. Thirteen scientists or technicians died from malignant neoplasm of the intestine $(E=6 \cdot 4, S M R=203,95 \%$ CI 108-347).

There was a tendency for mortality from all the digestive neoplasms to decrease with increasing year of entry. Mortality from malignant neoplasms of the stomach tended to decrease with increasing time since first employment (table 5) but there was no clear pattern by time since first employment for the other disease groups.

\section{Malignant neoplasms of the respiratory system}

There were only 26 deaths from malignant neoplasms of the larynx; 15 of these were from refinery $\mathrm{J}(\mathrm{E}=8 \cdot 7, \mathrm{SMR}=173,95 \% \mathrm{CI} 97-288)$ and they were spread across many job groups.

Although mortality from malignant neoplasms of the lung was again clearly decreased in the second follow up period the trend was for increasing mortality from this disease as the calendar period of follow up increased. Mortality was raised for riggers and storemen, and clearly raised for labourers (see table 6).

In the first follow up period there was an excess of observed deaths from malignant neoplasms of the nasal cavities and sinus compared with those expected, particularly at refinery J. There were no further deaths from this cause in the second follow up period.

\section{Melanoma}

The raised mortality from melanoma found in the first follow up period continued in the second follow up period, although to a slightly lesser extent. Table 10 summarises some of the results for this disease. The observed deaths were more than those expected in five of the eight refineries but especially at refinery $\mathrm{H}$. Excesses of observed deaths compared with those expected were found overall for operators, administrative, clerical and managerial staff, and other craftsmen. There was a tendency for mortality to increase with increasing year of entry, with a corresponding decrease by time since first employment (table 5).

\section{Malignant neoplasms of the genitourinary system}

In the second follow up period mortality from malignant neoplasm of the prostate was again slightly high, with that of malignant neoplasms of the bladder still low, although rather higher than in the first follow up period. The observed deaths from malignant neoplasm of the kidney were similar to those expected in both follow up periods.

There was clearly increased mortality from malignant neoplasms of the prostate in one refinery ( $B$; $\mathrm{O}=40, \mathrm{E}=27 \cdot 7, \mathrm{SMR}=144,95 \%$ CI 103-197). Eight of these men were foremen $(E=3.6$, $\mathrm{SMR}=222,95 \%$ CI 96-437), and five were fitters $(\mathrm{E}=1 \cdot 1, \mathrm{SMR}=477,95 \%$ CI $155-1114)$. There was also raised mortality overall from malignant neoplasms of the prostate in operators due mainly to increased mortality in operators at refinery $\mathrm{J}$ $(\mathrm{O}=18, \mathrm{E}=11.9, \mathrm{SMR}=151,95 \% \mathrm{CI}$ 90-239).

Mortality from malignant neoplasms of the prostate and bladder tended to decrease with increasing year of entry whereas malignant neoplasm of the kidney showed the opposite pattern. There were no clear patterns of mortality by time since first employment.

\section{Malignant neoplasms of the brain and central nervous system}

The mortality from this disease group was higher in the second follow up period than in the first, but still lower than expected. There were no patterns of raised mortality for this disease group.

\section{Malignant neoplasms of the lymphatic and haematopoietic tissue}

In general the numbers of observed deaths in these disease groups were small, making interpretation of the results difficult. No raised mortality was found in three of the groups, namely reticulum cell sarcoma, Hodgkin's disease, and other neoplasms of the 
lymphoid tissue. Mortality from lymphosarcoma increased in the second follow up period to give 18 deaths in total. Thirteen of these were from one company, at refinery $\mathrm{H} \quad(\mathrm{O}=5, \mathrm{E}=1 \cdot 7$, $S M R=297,95 \%$ CI 97-694), and refinery J $(\mathrm{O}=8, \mathrm{E}=3.9, \mathrm{SMR}=204,95 \%$ CI $88-401)$. Fifteen of the 18 deaths were day workers $(\mathrm{O}=8 \cdot 7$, SMR $=173,95 \%$ CI 97-286) but the deaths were spread across the job groups with several having slightly higher observed deaths than expected. Numbers were too small to show any patterns by year of entry or time since first employment. Mortality from multiple myeloma was lower than expected overall although one refinery (A) showed a pronounced excess based on only five deaths $(E=1 \cdot 6, S M R=307,95 \%$ CI 100-717).

Details of the results for leukaemia have been reported elsewhere. ${ }^{3}$ Briefly, the observed and expected deaths were similar in both follow up periods and only two types showed raised mortality overall, other myeloid leukaemia $(\mathrm{O}=7, \mathrm{E}=1 \cdot 0$, SMR $=678,95 \%$ CI 273-1397) and monocytic leukaemia $(\mathrm{O}=7, \mathrm{E}=3 \cdot 2, \mathrm{SMR}=221,95 \% \mathrm{CI}$ 89-435). There were 14 observed deaths from leukaemia at refinery $\mathrm{D}(\mathrm{E}=8 \cdot 6, \mathrm{SMR}=164,95 \%$ CI 89-2751), 12 of which were myeloid leukaemia $(E=4.98, S M R=241,95 \%$ CI 124-421). This refinery showed excess mortality for acute myeloid leukaemia $(\mathrm{O}=7, \mathrm{E}=3.3, \mathrm{SMR}=210,95 \% \mathrm{CI}$ 84-433) and other myeloid leukaemia $(\mathrm{O}=2$, $\mathrm{E}=0 \cdot 1, \mathrm{SMR}=1621,95 \%$ CI 196-5854). There were also three deaths from leukaemia at refinery $\mathrm{G}$ $(E=0 \cdot 8, S M R=393,95 \%$ CI 81-1149); two of these were chronic lymphatic leukaemias. Twenty one of the 68 deaths from leukaemia were in operators $(E=17 \cdot 3, S M R=123,95 \% C I 75-186)$ and six of the seven deaths from other myeloid leukaemias were in operators.

\section{Discussion}

Before comment on the results of this cohort study it is appropriate to indicate some of the limitations. The study examines mortality only. It is therefore dependent on the completeness and accuracy of the information on cause of death given by the death certificates.

The SMR (and its confidence interval) has been used in this study to describe the patterns of mortality and to search for consistency across variables and subgroups examined. The interpretation of results in the light of an overall healthy worker effect and the impact of the reanalysis of the data after a further 14 years follow up, as presented in tables 4 and 9 , must also be taken into account.

Differences in the mortality patterns between the eight refineries may be due to differences in the workforce or type of plant at the refineries. Details have been discussed previously ${ }^{2}$ but the refineries are of varying age, size, and complexity. Two refineries, A and D, came into use in the 1950s and the others were all expanded at this time. The patterns of entry to and exit from the refineries were all similar with the populations expanding in the 1950 s and decreasing in the 1960s. The distributions by birth year were also similar, with the exception of refinery $\mathrm{F}$ where $16 \%$ of the study population was born before 1900 compared with $5 \%$ in the other refineries. With the exception of refinery $G$, which was a bitumen manufacturing refinery, all had comparable crude oil processing plants. Refineries B and J also had some chemical plants but it was not possible to distinguish oil workers from chemical workers.

The large size of the cohort was the reason why only the last job title for leavers (or current title for those in employment at 31 December 1975) was collected to define the occupational group. Caution is thus necessary when interpreting the analyses by job defined in this way. No information was collected on job history either within or outside the oil industry; nor were data on exposures to potential hazards available. Methods of monitoring data on exposures to the many substances present were often unreliable, not regularly carried out, or not documented, until the late 1960 s when the need for monitoring became more recognised. ${ }^{44}$ It has been suggested that analyses of job title may detect associations that are not detectable by substance analysis, however, if the substance occurs in many occupations but is only a risk in the circumstances of a particular occupation. ${ }^{45}$

Dates of leaving for those who were in post on 31 December 1975 were not obtained from the oil companies in this second follow up. For this reason, analyses by duration of employment could not be carried out. The mean duration of employment before 1976 was 13.2 years. Assuming those in post at 31 December 1975 worked an average of seven years in the second follow up the mean duration of employment of the cohort would be between 15 and 16 years by the end of 1989 .

The person-years have increased by about 360000 and the number of deaths has more than doubled from 4406 in the first follow up to 1975 to 10193 at 31 December 1989. The overall relative mortality of the study population, however, remained low, a continuation of the healthy worker effect. This may reflect both the initial selection of a healthy workforce and subsequent standard of medical care, industrial hygiene, and standard of living, and the comparison with the national population, which includes those in institutions, in unstable employment, or in ill health during their working life.

This lowered mortality was also reflected in many of the numerically large non-malignant causes of 
death such as ischaemic heart disease and respiratory disease. Some of the individual job groups showed slightly raised mortality from specific nonmalignant disease groups, in particular labourers. The expected deaths were not adjusted to take into account variations in mortality by social class. Many of the diseases for which raised mortality was found in labourers, such as cerebrovascular disease, bronchitis, and pneumonia, show clear trends in the population of England and Wales from low to high mortality for social classes I to $V .{ }^{46}$ If adjustment had been made to the expected numbers of deaths for labourers with the data for social class $\mathrm{V}$ for these disease groups some of the raised mortality would be greatly diminished or disappear altogether.

Accidental fire and explosion, a plausible potential occupational hazard, continued to exhibit raised mortality although the number of deaths were small.

The consistently raised mortality from diseases of the arteries, and in particular from aortic aneurysm, is more difficult to interpret, because it is high across several refineries, age groups, and job groups. The patterns for this disease contrast with those of most of the heart disease groups, in which mortality is generally low. Increased mortality from aortic aneurysm has also been found in a study of Canadian oil distribution and marketing workers (AR Schnatter, unpublished data).

Mortality from all neoplasms was once again lower than expected, due mainly to pronounced deficits in malignant neoplasm of the lung. There was a trend, however, for increasing mortality from malignant neoplasms of the lung as the follow up period increased, with raised mortality for labourers. It has been suggested that the amount of smoking by refinery employees may be somewhat less than that of the general population. ${ }^{28}$ It may be that smoking habits change after leaving and this may cause the mortality from lung cancer to increase as the cohort becomes older, although there are no data to substantiate this. Two small surveys (unpublished) carried out recently in two of the refineries in this study found that roughly $20 \%$ of those surveyed were current smokers compared with $33 \%$ of men aged 15 to 64 in England and Wales. ${ }^{47}$ There was a trend for the proportion of smokers to increase as age increased in the refineries, similar to the trend in England and Wales. Only $15 \%$ of those aged under 40 smoked in the refinery survey, however, compared with $33 \%$ in the population of England and Wales. There was also a suggestion from one of the surveys, although based on small numbers, that those in the refinery smoked less than the general population, $40 \%$ in the refinery survey smoking less than 20 cigarettes a day compared with $18 \%$ of the men aged 15 to 64 in England and Wales who were current smokers.

There were some raised mortality patterns for malignant neoplasms of the digestive tract, in particular for malignant neoplasm of the stomach at refineries $\mathrm{F}$ and $\mathrm{J}$. Two job groups were involved, operators and labourers, and the SMR for social class $\mathrm{V}$ in the general population was again high. No adjustment was made to the expected deaths to take into account known regional variations in mortality in England and Wales but both $F$ and $J$ refineries are situated in areas with high rates of stomach cancer (the SMR for the region in which refinery $F$ is situated was 113 and that for the region in which refinery $\mathrm{J}$ is situated was 123$)^{48}$ and adjustment for both social class and regional variations would have reduced or removed the excess mortality.

The raised mortality from melanoma continued in the second follow up, in particular at refinery $\mathrm{H}$, and was found in three very different job groups. Three other refinery studies have also found excesses from this disease ${ }^{16} 2729$ but as yet no occupational cause linked to the oil industry has been suggested.

The slightly raised mortality from malignant neoplasm of the prostate continued in the second follow up period, with operators again having clearly increased mortality at refinery J. Overall mortality from this disease was also raised appreciably at refinery B. Several other studies have found raised mortality for malignant neoplasms of the prostate. ${ }^{21} 303135$ Unlike other studies, ${ }^{1849}{ }^{50}$ the present study has not found any evidence of raised mortality for malignant neoplasms of the kidney or brain.

Particular interest has been paid to mortality from leukaemia and lymphosarcoma and their possible relation to exposure to benzene and other solvents. ${ }^{5152}$ In this study there was increased mortality from lymphosarcoma at two refineries although there are only 18 deaths in total.

The total observed deaths from leukaemia were once again slightly lower than those expected and clearly increased mortality was found in only one refinery (D). This was from myeloid leukaemia in particular. Just under a third of the deaths from leukaemia were in operators.

Although the contributory causes of death on the death certificates were coded and entered into the database no detailed analyses of these have so far been carried out. The deaths with a malignant neoplasm as a contributory cause were investigated, however. For example, there were 17 contributory cases of malignant neoplasms of the stomach, 22 of the intestine, 42 of the lung, and 41 of the prostate. The ratio of the number of total mentions of each malignant neoplasm: the number of underlying causes of that disease group in the study population 
was compared with the ratios from the population of England and Wales ${ }^{46}$ and found to be similar.

In conclusion, the mortality of the oil refinery study population continues to be lower than that of the general population, both overall and from many of the numerically large disease groups. This current analysis has highlighted some issues that may warrant further investigation. The refinery population is now largely flagged at the NHSCRs and as further deaths occur in the cohort the death certificates will be provided. Further patterns of mortality can thus be monitored as required. Specific issues of particular concern-for example, the increased mortality from melanoma and aortic aneurysmcould be further investigated by carrying out nested case-control studies in which the deaths from the disease of interest are matched to controls selected from the rest of the study population. Further details such as job history and estimates of exposure to potential hazards might then be obtained and compared for the limited number of cases and controls.

The research team included Ms Linda McFadyen who was responsible for the input and maintenance of the study database. The study was funded by the Institute of Petroleum. Thanks go to the IP working party under the chairmanship of $\mathrm{Dr}$ Charles Binns, and to Professor Mark Cross and other members of the Department of Mathematics, Statistics and Computing at Thames Polytechnic for their help and advice on the study. I am grateful to OPCS, the DSS and the Registrar General for Scotland for carrying out the flagging and tracing of the study population. I would also like to acknowledge the key part played by the late Michael Alderson both in the first study follow up and in initiating the second follow up.

1 Rushton L, Alderson MR. An epidemiological survey of eight oil refineries in Britain. Br F Ind Med 1981;38:225-34

2 Rushton L, Alderson MR. An epidemiological survey of eight oil refineries in the UK-final report. London: Institute of Petroleum, 1980.

3 Rushton L. A 39 year follow-up of the UK oil refinery and distribution centre studies: results for kidney cancer and leukaemia. Environ Health Perspect (in press) 1993.

4 Gradiski D, Vinot J, Zissu D, Limasset JC, Lafontaine M. The carcinogenic effect of a series of petroleum-derived oils on the skin of mice. Environ Res 1983;32:258-68.

5 Holland JW, Rahn RO, Smith LH, Clark BR, Chang SS, Stephens TJ. Skin carcinogenicity of synthetic and natural petroleums. F Occup Med 1979;21:614-8.

6 Jarvholm B, Lavenius B. Mortality and cancer morbidity in workers exposed to cutting fluids. Arch Environ Health 1987;42:361-6.

7 Miller BG, Cowie HA, Middleton WG, Seaton A Epidemiologic studies of Scottish oil shale workers: III Causes of death. Am f Ind Med 1986;9:433-46.

8 Mehlman MA. Dangerous properties of petroleum-refining products: Carcinogenicity of motor fuels (Gasoline). Teratogenesis, Carcinogenesis, and Mutagenesis 1990;10: 399-408.

9 Higginson J, Muir C, Buffler A. The epidemiology of renal carcinoma in humans with a note on the effect of exposure to gasoline. In: Proceedings of a workshop on kidney cancer effects of hydrocarbons. Washington DC: American Petroleum Institute, 1983.

10 Austin SG, Schnatter AR. A cohort mortality study of petrochemical workers. F Occup Med 1983;25:304-12.

11 Bertazzi PA, Pesatori AC, Zocchetti C, Latocca R. Mortality study of cancer risk among oil refinery workers. Int Arch Occup Environ Health 1989;61:261-70.

12 Christie D, Robinson K, Gordon I, Bisby J. A prospective study in the Australian petroleum industry. I Mortality. $B r f$ Ind Med 1991:48:507-10.

13 Divine BJ, Barron V, Kaplan SD. Texaco Mortality study. I. Mortality among refinery, petrochemical, and research workers. F Occup Med 1985;27:445-7.

14 Hanis NM, Shallenberger LG, Donaleski DL, Sales EA. A retrospective mortality study of workers in three major U.S. refineries and chemical plants part 1: Comparisons with $U S$ population. f Occup Med 1985;27:283-92.

15 Kaplan SD. Update of a mortality study of workers in petroleum refineries. F Occup Med 1986;28:514-6.

16 Nelson NA, Van Peenan PFD, Blanchard AG. Mortality in a recent oil refinery cohort. F Occup Med 1987;29:610-2.

17 Theriault G, Provencher S. Mortality study of oil refinery workers: Five year follow up. F Occup Med 1987;29:357-60.

18 Waxweiler RJ, Alexander V, Leffingwell SS, Haring M, Lloyd JW. Mortality from brain tumour and other causes in a cohort of petrochemical workers. I Natl Cancer Inst 1983; 70:75-81.

19 Wong O, Morgan RW, Bailey JW, Swencicki RE, Claxton K, Kheifets L. An epidemiological study of petroleum refinery employees. Br F Ind Med 1986;43:6-17.

20 Thomas TL, Waxweiler RJ, Moure-Eraso R, Itaya S, Fraumeni JF. Mortality patterns among workers in 3 Texas oil refiners. f Occup Med 1982;24:135-41.

21 Morgan RW, Wong O. An epidemiologic analysis of the mortality experience of Mobil Oil Corporation employees at the Beaumont, Texas, refinery. Report submitted to Mobil Oil Corporation. 1984.

22 Savitz DA, Moure R. Cancer risk among oil refinery workers. A review of epidemiologic studies. F Occup Med 1984; 26:662-70.

23 Harrington JM. Health experience of workers in the petroleum manufacturing and distribution industry: A review of the literature. Am f Ind Med 1987;12:475-97.

24 Wong O, Raabe GK. Critical review of cancer epidemiology in petroleum industry employees, with a quantitative metaanalysis by cancer site. Am $\mathcal{F}$ Ind Med 1989;15:283-310.

25 Raabe GK. Kidney cancer epidemiology in petroleum related studies. In: Proceedings of a workshop on kidney effects of hydrocarbons. Washington DC: American Petroleum Institute, 1983:393-408.

26 Fox AJ, Collier PF. Low mortality rates in industrial cohort studies due to selection for work and survival in the industry. British fournal of Preventive and Social Medicine 1976; 30:225-30.

27 Schottenfeld D, Worshauer ME, Zauber AG, Meikle JG, Hart BR. A prospective study of morbidity and mortality in petroleum industry employees in the United States - a preliminary report. In Peto R, Schneiderman M, eds: Banbury report 9: Quantification of occupational cancer. Cold Spring Harbour, NY: Cold Spring Harbour Laboratory, 1981: $247-65$.

28 Van Peenan PFD, Blanchard AG, Wolkonsky MD. Smoking habits of oil refinery employees. Am $\mathcal{F}$ Public Health 1984; 74:1408-9.

29 Reeve GR, Thomas TL, Kelly VF, Waxweiler RJ, Itaya S. A proportionate mortality study of an oil, chemical and atomic workers local in Texas City, Texas. Ann NY Acad Sci 1982;381:54-61.

30 Wen CP, Tsai SP, Weiss NS, Gibson RL. Long-term mortality study of oil refinery workers: V Comparison of workers hired before, during, and after world war 2 (1940-1945) with a discussion of the impact of study designs on cohort results. Am F Ind Med 1986;9:171-80.

31 Wen CP, Tsai SP, Weiss NS, Gibson RL, Wong $O$, McClellan WA. Long-term mortality study of oil refinery workers. IV. Exposure to the lubricating-dewaxing process. f Natl Cancer Inst 1985;74:11-8.

32 Norrell S, Ahlbom A, Olin R, et al. Occupational factors and pancreatic cancer. $\mathrm{Br}$ F Ind Med 1986;43:775-8.

33 Thomas TL, Waxweiler RJ, Crandall MS, White DW, 
Moure-Eraso R, Fraumeni JF. Cancer mortality patterns by work category in three Texas oil refineries. Am f Ind Med 1984;6:3-16.

34 Hanis NM, Stavraky KM, Fowler JL. Cancer mortality in oil refinery workers. F Occup Med 1979;21:167-74.

35 Morgan RW, Wong O. Final Report. An epidemiological mortality study of Mobil Oil Corporation employees at the Paulsboro, Nezw fersey, refinery. Report submitted to Mobil Oil Corporation, 1985.

36 Wen CP, Tsai SP, McClellan WA, Gibson RL. Long-term mortality study of oil refinery workers. I. Mortality of hourly and salaried workers. Am f Epidemiol 1983;118:526-42.

37 Blot WJ, Brinton LA, Fraumeni JF, Stone BJ. Cancer mortality in US countries with petroleum industries. Science 1977; 198:51-3.

38 Hoover R, Fraumeni JF. Cancer mortality in US countries with chemical industries. Environ Res 1975;9:196-208.

39 Kaldor J, Harris JA, Glazer E, et al. Statistical association between cancer incidence and major-cause mortality, and estimated residential exposure to air emissions from petroleum and chemical plants. Environ Health Perspect 1984; 54:319-32.

40 Darby SC, O Hagan JA, Kendall GM, Doll R, Fell TP, Muirhead CR. Completeness of follow up in a cohort study of mortality using the United Kingdom National Health Service Central Registers and records held by the Department of Social Security. F Epidemiol Community' Health 1991;45:65-70.

41 Gardner MJ, Altman DG. Statistics with Confidence. London: British Medical Journal, 1989.

42 Jones DR, Rushton L. Simultaneous Inference in epidemiological studies. Int $\mathcal{F}$ Epidemiol 1982;11:276-82.
43 Jennison C, Turnbull BW. Interim analyses; the repeated confidence interval approach. Foumal of the Royal Statistical Society Series A 1989;51:305-361.

44 Paustenbach DJ, Price PS, Ollison W, et al. A re-evaluation of benzene exposure for the plioform (rubber worker) cohort (1936-1976). Toxicol Environ Health 1993 (in press).

45 Siemiatycki J, Dewar R, Richardson L. Costs and statistical power associated with the five methods of collecting occupational exposure information for population-based case-control studies. Am f Epidemiol 1989;130:1236-46.

46 Office of Population Censuses and Surveys. Mortality statistics cause 1986 series DH2 No.13. London: HMSO, 1988.

47 Office of Population Censuses and Surveys Social Survey Division. General Household Survey 1988. London: HMSO, 1990.

48 Britton M. Mortality' and geography, a review in the mid 1980's England and Wales. London: HMSO, 1990. (Series DS No.9.)

49 Thomas TL, Waxweiler RJ, Crandall MS, et al. Brain cancer among OCAW members in three Texas oil refineries. Ann NY Acad Sci. 1982;381:120-9.

50 Bond GG, Cook RR, Wight PC, Flores GH. A case-control study of brain tumour mortality at a Texas chemical plant. $\mathcal{f}$ Occup Med. 1983;25:311-86.

51 Swaen GMH, Meijers JMM. Risk assessment of leukaemia and occupational exposure to benzene. $\mathrm{Br} F$ Ind Med. 1989;46:826-30.

52 Austin H, Delzell E, Cole P. Benzene and Leukaemia-A review of the literature and a risk assessment. Am 9 Epidemiol 1988;127:419-39.

Accepted 17 August 1992 